\title{
Carsten Thau
}

\section{Mysterierne i haven til Anstey}

\section{- om Peter Greenaways Tegnerens kontrakt}

\author{
Natur erscheint als vorgeordnetes Abenteuer von Repräsentation \\ und Lust, mit einem Zauberschloss der Mitte. \\ Ernst Bloch
}

Peter Greenaways debut som spillefilmsinstruktør er blevet mødt med entusiasme på biennalen $\mathrm{i}$ Venezia, $\mathrm{i}$ diverse filmmagasiner og $\mathrm{i}$ den engelske dagspresse, som har vejret morgenluft for britisk filmproduktion. Ukendt for de fleste har Greenaway imidlertid kreeret over en snes "eksperimentalfilm", fra nogle af få minutters varighed til den 3 timer lange The FALLs, som behandler 92 mennesker i hvis navn stavelsen fall indgår.

En anden film, Act of God, handler om en serie mennesker, der har det tilfælles, at de er blevet ramt af lynet, et "faktamønster som unddrager sig enhver klassificering", som han selv siger i et interview. Ikke desto mindre søger filmen efter skjulte spor af fælles træk i deres tilværelse. Greenaways film er "ironiske" stykker, optaget af de sære ordenssystemer, som fremgår af f.eks. leksikale opslagsværkers alfabetiske tilrettelæggelse af omfattende materialesamlinger. Greenaway er en højt gearet intellektuel, der med usvækket forbløffelse iagttager verden som et komplekst net af betydnings- og ordenssystemer og underkaster dem humoristisk granskning, alt imens han begår det kunststykke på en gang at holde tungen lige $\mathrm{i}$ munden og stikke den $i$ kinden.

Det kan ikke undre, at han har følt sig tiltrukket af barokkens forestilling om det kosmiske teater og har givet sin personlige vision af denne forestilling i Tegnerens kontrakt, som foregår i 1600-tallets England. En film spækket med skøre manierismer i handling og gestus, en vanvittigt kompliceret intrige og et utal af allusioner til periodens malerkunst (Poussin, Lorrain, de la Tour), filosofi (Descartes, Locke og Leibniz), havekunst (William Kent) og dertil litterære inspirationer, rækkende fra Restaurationstidens komedier til Borges og Calvino. For at der ikke skal mangle noget kan filmen i tilgift oplagt betragtes som en æstetikteoretisk fabel over impulser 
fra Panofskys lille essay 'Et in Arcadia Ego' og Walter Benjamins undersøgelser af allegoribegrebet. Alt dette pakket ind i et Agathe Christie plot efter modellen: mord på herregården.

Greenaway nævner selv hovedparten af disse inspirationskilder og med rette, forsåvidt som de ikke kun gør sig gældende som mere eller mindre tilfældige referencer, men er bærende for den måde filmen er konciperet på. Er man tilstrækkelig informeret til at få færten af disse sammenhænge, føler man sig for alvor som det Taine kaldte en person af en betydelig "enzyklopædisk uvidenhed", når man forlader biografen. At ville analysere filmen er et barokt forehavende helt i filmens ånd.

Tegnerens kontrakt er fyldt med vittigt guf i slægt med de reklamebilleder man undertiden støder på, hvor fornemmelsen opstår, at de er lavet af en snild semiolog, der ad omveje er havnet $i$ den grafiske branche. For publikum giver filmen anledning til megen samtale og i New York Times er den blevet omtalt som "the coffeetable movie of the year." Filmens appel ligger ikke mindst $i$ at være en brain-teaser og et stramt gennemført illusionistisk trapez-nummer, men det er også en meget smuk film. Aldrig var græsset grønnere eller busketterne mere opulente i den engelske have, dog heller aldrig serveret med så lille et spillerum for sværmerisk hengivelse. Filmens tempo og tætte væv af musik, informationsfyldte billeder og en rivende væg-til-væg dialog, bundet sammen af en kriminalistisk intrige, hvor selv de mindste detaljer kan være vigtige spor og i hvert tilfælde har "betydning", stikker hele tiden sin nagende pegefinger gennem det skønne skin, som overhovedet filmens demonstrativt bevidste brug af sine virkemidler.

Men er der ikke også noget om kultur og klasse? Så ganske afgjort. Persongalleriet består overvejende af brokade-lavadel, grådige parvenuer, hvis an-skuelser og repræsentationsformer blotlægges pedantisk som $i$ en anatomisk forelæsning. Dersom vi traditionelt opfatter en ironiker som en person, der nok kan se, at den er gal med det bestående, men ikke kender det nye, eller rettere ikke kan finde nogen slagkraftig adresse for det $\mathrm{i}$ vores del af verden, så er Greenaways film ironisk og kendetegnende for 1980'ernes fascineretskrækslagne iagttagelse af det upersonligt kollektives overgribende magt og formeringsevne. Greenaways behændige jongleren med det mangetydige udgør imidlertid en vital aktivitet, som er med til at holde vandene åbne, fordi den tvinger til at få fat $i$ forskellen mellem at se (og forstå) og så blot kikke på. Det er det Tegnerens kontrakt handler om. 
Greenaways forsmag for det tvetydige, leder ikke til en kyniskresigneret opfattelse af, at alle elementer er lige-gyldige, den stadige destabilisering af entydig mening gøres ikke til gehalt, men til ansporing. Filmen besidder en lidenskab for spil, et sprælsk antrit og et humoristisk overskud som inddrager filmen selv som medium, svarende til udforskninger $\mathrm{i}$ de sidste årtiers billedkunst, litteratur og arkitektur. Filmens betydelige dybsindighed ligger i overfladen, man mærker ikke noget metafysisk åndedrag i nakken, er snarere genstand for en forførende, plausibel kunstfærdighed, der virker længe efter man har set filmen.

\section{Historisk baggrund}

Filmen finder sted i 1694, nogle få år efter William of Orange havde sikret den nationale enhed og protestantiske overhøjhed med sejren ved Boyne og Glencoe-massakren. Optakt til en periode med fred på hjemmefronton og konsolidering af imperiet. Greenaway opfatter året som et vendepunkt i engelsk historie: "Det var det år litterær censur blev ophævet og året for Bank of Englands grundlæggelse. Det katolske Stuart-dynasti var fejet til side og en ny merkantil protestantisk etos satte ind".

Den protestantiske lavadel understreger sin position ved at bygge mægtige huse og afpolstre dem omhyggeligt med kultiverede haver og parker. Man etablerer kunstsamlinger efter italiensk forbillede, dyrker eksperimentel botanik og understøtter $i$ behersket omfang udøvende kunstnere. For et beskedent honorar ansættes malere til at portrættere ejernes koner, deres heste, bygninger og haver.

\section{Den kriminalalistiske intrige}

Handlingen udspiller sig på herresædet Compton Anstey i Wiltshire, som den ambitiøse og anskrevne landskabskunstner $M r$. Neville besøger ud på sommeren. Filmens forspil er en soiréee, hvor ræveagtige ansigter med sarkastisk komik og i sylespidse vendinger taler løs - i skæret fra stearinlys. Under selskabet annoncerer ejeren $M r$. Herbert, at han vil foretage en rejse til Southhampton, for at tage del i nogle frivole fornøjelser, forstår man .

Mrs. Herbert, den oprindelige arving til Anstey, foreslår $\mathrm{Mr}$. 
Neville, at han, medens manden er væk, skal modtage det opdrag på tolv dage at udføre tolv eksteriørbilleder af huset med fæstningsgrav og have. Tegningerne er tænkt som en gave til manden, når han kommer tilbage. Den flotte, men noget kradsbørstigt arrogante Neville lader sig overtale til at indgå kontrakten, da han i tilgift får løfte om seksuelt at kunne forlyste sig med Mrs. Herbert efter forgodtbefindende. Alt noteres i en kontrakt, som udformes af godsforvalteren $M r$. Noyes og som i øvrigt sikrer Neville kost, logi samt at synsfeltet for hans tegninger på særligt fastsatte tidspunkter er ryddet for alt uvedkommende: redskaber, tyende, løsøre m.v.

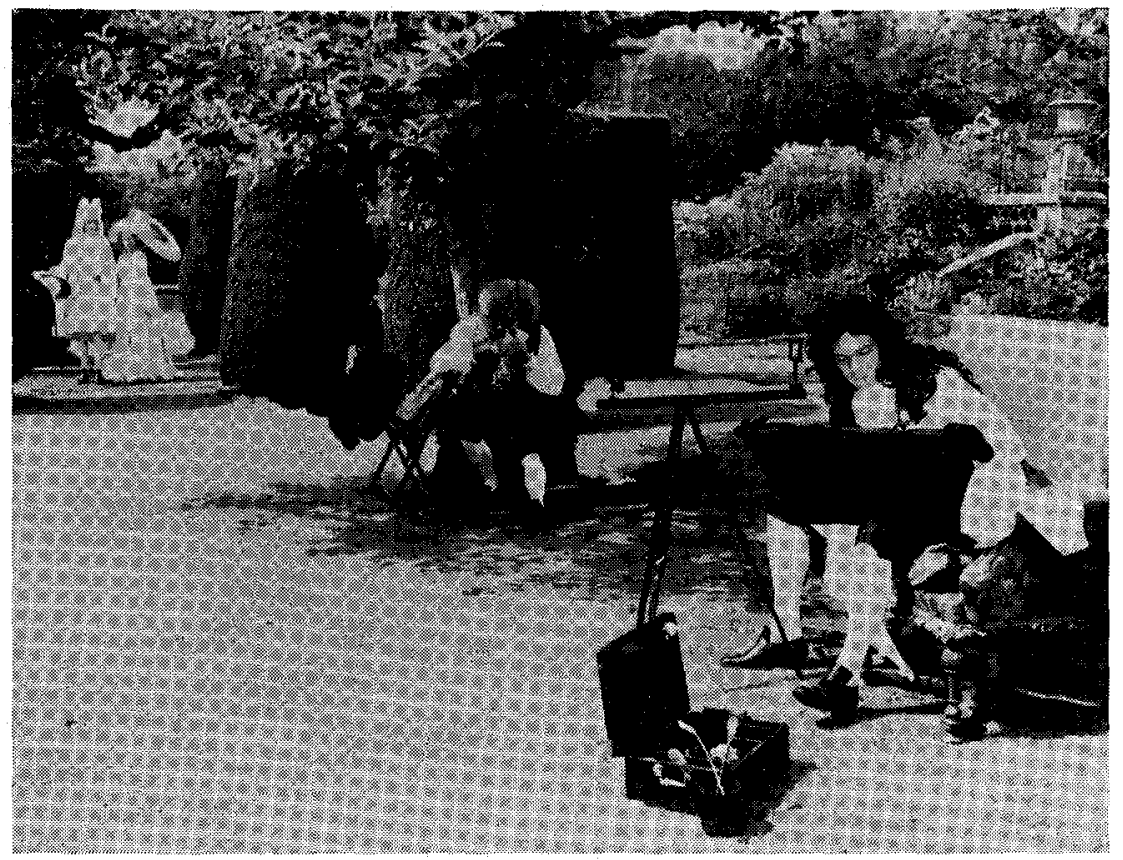

Mr. Neville arbejder i haven, i mellemgrunden hans um ælende medhjælper. Mr.og Mrs. Thalman ser til. Mr. Thalman med horn i parykken.

Neville går i gang med sin opgave som om det drejede sig om en paramilitær operation. Hans tegninger sigter mod den mest skarpskårne, nøjeregnende gengivelse af motiverne, i en belysning der gengiver de ideale proportioner. I begyndelsen småirriteret, accepterer han mere eller mindre bevidst uregelmæssigheder og fæstner på papiret ting og sager, som har sneget sig ind $i$ hans rigoristisk kontrollerede kompositioner: en stige som fører op til et vindue (til 
husets datter, Mrs. Thalmans værelse), en henslængt skjorte og andetsteds en jakke, der ligger til tørre. Efter han har færdiggjort de seks første tegninger opsøges han af datteren Sarah Thalman, gift med en vindtør, tyrannisk tysk emigrant, som hader katolikker og for sit vedkommende kun pønser på at overtage Anstey og indføre effektive principper for driften af godset.

Den sensitive og saftigt vakre Mrs. Thalman giver Mr. Neville en lektion i forskellen mellem den intuitive og den intellektuelle kunstners valg af motivets bestanddele: "Mr. Neville, I have grown to believe that a really intelligent man makes an indifferent painter, for painting requires a certain blindness - a partial refusal to be aware of all options. An intelligent man will know more about what he is drawing than he will see. And in the space between knowing and seeing he will become constrained, unable to pursue an idea strongly..." Hun spørger ham, hvilken "obscure allegory", der ligger til grund for de sære genstande, der har lejret sig i hans i øvrigt rendyrkede motiver. Samtidig har fornemmelsen af, at Mr. Herbert, der tog til Southhampton for at jagte luddere, i en mere total forstand er "borte", bredt sig på godset. Parallelt med, at skjorten og jakken har levet deres eget liv i Nevilles tegninger, dukker Mr. Herberts hest op, halt og herreløs. Et ubestemmeligt tomrum breder sig i filmens centrum. Er han blevet myrdet? Tilhører klædningsstykkerne godsets ejer? Hvem har lagt dem, hvor de ligger, og hvilken rolle spiller de i Nevilles billeder?

Over for Neville anfører Sarah Thalman, at hans billeder bærer vidnesbyrd om en skjult skandale, "hints of some dreadfull misadventure". Under alle omstændigheder er Neville under mistanke, for "at tegne et motiv er også at begære det". Mrs. Thalman påtager sig at beskytte ham under udførelsen af de resterende billeder imod at han stiller sig til rådighed for hendes erotiske behov, altså uden den summariske, seksuelle underkastelse, som kendetegner hans traktering af moderen, Mrs. Herbert, der hver gang han på klokkeslet gør sine krav gældende opfører sig som om hun skal udsættes for et kiropraktisk greb. Også kontrakten mellem Mr. Neville og Mrs. Thalman optegnes af godsets forvalter, Mr. Noyes. Da Sarah Thalmans ægtemand, den impotente og sterile Mr. Thalman, opdager sin kones utroskab, fortolker han tegningernes allegoriske fabel - stigen til hustruens værelse og hendes hund efterladt foran badstuen - som forførerens pralende rebus. Han beslutter sig derfor til at købe tegningerne.

$\mathrm{Da}$ den 12. tegning er færdiggjort fiskes liget af godsejeren op af 
voldgraven. Neville forlader Anstey for at arbejde for en anden aristokrat. Godsforvalteren Mr. Noyes, der i sin ungdom var forlovet med Mrs. Herbert og i øvrigt afskyr Mr. Neville for hans erotiske eskapader, tilbyder Mrs. Herbert at bytte tegningerne mod de seksuelle kontrakter, fordi han er bange for at tegningerne rummer indicier på et mordkomplot, han kunne anklages for at stå bag, fordi han gennem giftermålet med Mrs. Herbert ville være blevet herre til Anstey. Efter nogen tid vender Mr. Neville pludselig tilbage for at færdiggøre en 13. tegning. Tegneren, der hidtil har været klædt i sort, kommer nu anstigende $\mathrm{i}$ hvidt og har aflagt sin stikkende arrogance. Keder han sig hos hertugen i nabolaget og savner sin seksuelle morskab på Anstey? Sigter han mod at gifte sig med den velhavende enke? Eller vil han blot færdiggøre sin cyklus af tegninger, så den rummer spor af alle begivenheder, også den finale?

Efter et fornyet og mere forløst kærlighedsmøde med Mrs. Herbert fortæller hun ham, at han var led i et komplot gående ud på at gøre den barnløse datter gravid, så arvefølgen kunne sikres. Om aftenen udfører han ved stearinlys sin sidste tegning, forestillende en herreløs rytterstatue i bronze, som står ved voldgraven på det sted $\mathrm{Mr}$. Herbert's lig blev fundet. Her sker det blodige, gruopvækkende mord, som overrumplende fører det 17 . århundredes brutalitet ind $\mathrm{i}$ filmen. Mr. Thalman, Mr. Noyes, maskeklædte og med følge, omkredser Neville, dikterer ham en tredie kontrakt, prikker hans øjne ud og slår ham med køller til han dør, mens tegningerne går op i luer.

\section{Ejendommen tegner billedet}

Filmen vender og drejer fænomenet repræsentation. I første række en klasses repræsentation af sig selv gennem ejendom og levevis. $\mathrm{Mr}$. Herbert prioriterer selv sine besiddelser: "a house, a garden, a horse, a wife, in that preferential order", og de fleste af Ansteys beboere stræber efter at udvide eller opretholde deres position gennem besiddelse af ejendom. Herskabet på Anstey har dog ikke noget praktisk livtag med attributterne for deres magt, de spankulerer rundt $p a ̊$ ejendommen som $i$ et scenografisk arrangement og oplever deres verden som staffage. De er pomadiserede paryk-aktører, hvis titler og standsetiketter synes underlagt inflationær betydning gennem det almindelige opbrud i samfundet. Tegningerne dokumen- 
terer ejendommen ved at repræsentere den i kunstnerisk form, sort på hvidt - svarende til de kontrakter som indgås. Kontrakterne er bindeled i det reciprokke forhold mellem kunst, sex og ejendom, som filmen omhandler. Men ejendom har fortrinsstilling, den afgør hvilken form for mening eller betydning, der får lov til at leve.

Mr. Nevilles tegninger er anlagt efter strenge perspektiviske principper, samtidig med at hans blyant bevæger sig henover papiret med noget der ligner erotisk lidenskab. Barokkens storstilede udnyttelse af centralperspektivet - på teatret, i byplanlægningen og i havekunsten - må i filmens univers tænkes at rumme den sammensatte pointe, at perspektivet samtidig med at være et "universelt ordensprincip" også er verden set fra et enkelt øjepunkt, efter at en højere gudgiven enhed er brudt sammen (og erstattet af menneskers individuelle handlingsperspektiv). I sidste ende det individuelle menneskes strategiske blik på verden, for hvilket tingene ordner sig efter formelle principper - samtidig med at tingene ses som alenemed-sig-selv, som løsrevne isolerede og forgængelige objekter, sådan som de møder allegoriens sørgmodige blik ${ }^{1}$. I Mr. Nevilles tegninger møder vi på den ene side den rumligt klart affattede stabilisering og repræsentation af ejendommen og på den anden side, som vraggods efter den verserende kamp om ejendom, ejeren $\mathrm{Mr}$. Herberts skæbnesvangre klædningsstykker, som en skjult kode, en drilsk nisse der flytter med.

I overensstemmelse med det 17. århundredes filosofi er Neville besat af den akkurate, virkelighedstro detalje, hans billeder er tørre og sterilt nøjeregnende: "I try very hard never to distort or dissemble", bedyrer han, svarende til Descartes ideal om "clara et destincta perceptio" eller som ceremonimesteren på Versailles udtryke det "rien n'est beau que le vrai", en realisme som bygger på antagelsen om, at natur og fornuft er det samme. Alt får sin storhed gennem at blive indordnet som kolonner i en ligning. Greenaway nævner som forbilleder for sin billedstil Claude Lorrain, Georges de la Tour og Nicolas Poussin, hvoraf sidstnævnte i eminent grad komponerer ud fra stramme matematiske formler og lader det gyldne snit penetrere alle dele af billedfladen.

Dette er det ene aspekt som filmen driver sin muntre dialog med: den naive tillid til en fornuftig orden i geometriske arrangementer af verden, tidens ésprit géometrique. Understreget gennem Mr. Nevilles brug af perspektivramme, en optisk indretning til at fixére landskabet på papiret, der holder Poussins format 1:1,66, ligesom filmen selv. (Greenaway er indstillet på i en kommende forevisning 
af filmen på TV at sikre en afmaskning som lader denne proportion uforstyrret af skærmens runde hjørner). At Nevilles tegninger fordobles af filmen selv, at de er billeder i billedet, betones ydermere af, at der bortset fra et par korte panoreringer arbejdes med absolut statisk kamera og lange indstillinger.

Vi har altså at gøre med et kinesisk æeskesystem, hvor personerne repræsenteres af ejendommen og af haven, som en grøn skuesal, som repræsenteres af tegningerne, som igen repræsenteres af filmen, der tilsvarende dyrker en frontal, arkitektonisk komposition af sine billeder. Filmen vil tydeliggøre fotografens egen seen igennem søgeren for publikum (gennem Nevilles perspektivramme), og på film-

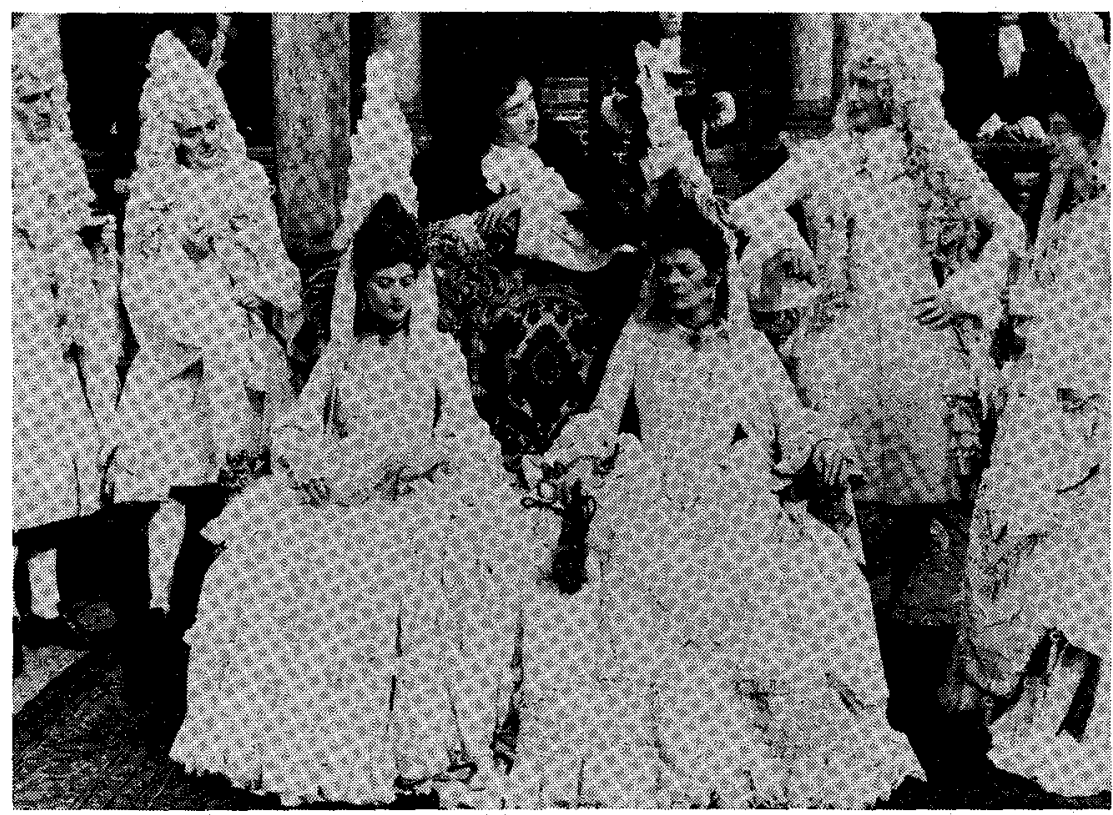

Herskabet på Compton Anstey i typisk symmetrisk opstilling. Siddende Sarah Thalman og Mrs. Herbert, flankeret af Mr. Noyes (til venstre) og Mr. Thalman. Lænet over rygstødet den kontraktsligt veludrustede Mr. Neville.

lærredet følger vi Nevilles begyndende skitser og afmærkninger på papiret, ser langsomt en stadig mere detaljeret verden træde frem. I tråd med at filmens billedkompositioner i øvrigt citerer malerier af Gainsborough (det berømte "Mr. and Mrs. Adams", som John Berger har analyseret ud fra "ejendomsmotivet"), Caravaggio, Ver- 
meer van Delft og adskillige andre. Sådan set er filmen en lang lektion over sammenhængen mellem ikonografi og socialhistorie, men gennemført med et vittigt overskud af leg med betydning, som ikke kan udmøntes i noget entydigt budskab. Meningen med de enkelte billeder opvejes af driften efter at finde en mening, som anspores hos publikum. Selve den refleksive proces kan siges at være budskabet. Bortset fra at filmfotografens billeder er forudorganiseret af forskellige referencer, så giver de ekstremt fastlåste kameraindstillinger indtryk af kølig, desengageret iagttagelse, hvadenten det observerede er stofbetrækket på en stol, en frugtopsats eller Nevilles erotiske omgang med Mrs. Herbert, der virker som retsmedicinske rekonstruktioner.

Den kølige iagttagelsesform er Nevilles egen under udførelse af tegningerne. Han samler sansedate i overensstemmelse med den samtidige engelske empiristiske filosofi hos John Locke, hvor bevidstheden i udgangspunktet er en tom tavle, og hvor det som fylder den er kommet gennem sansningen, således at forstå, at det som fylder bevidstheden er idéer, som repræsenterer de ydre objekter. Hvad der bliver fatalt for Neville er, at han er for enfoldigt optaget af sin lige-ud-ad-landevejen registrering af objekter $\mathrm{i}$ omverdenen og deres fornuftige arrangement $\mathrm{i}$ billedet, til at han forstår den rebus af mere vidtgående betydningsmønstre, der fungerer som et skjult maskineri. Han får grusomt på hattepulden for sin udtalelse i filmens start om, at han besidder "the power to create reality". Hans egendommelighed som kunstner kan ikke unddrage sig ejendomsbesidderens betydningshierarki. Han går til grunde, fordi han opfatter sine motiver umiddelbart og ikke ser dem formidlet af et machiavellistisk rænkespil. På sin aggressive facon tror han at tage herskabets besiddelser på kornet med sit optiske tegneredskab, at "arrestere" dem så at sige.

I en nøglescene inde $\mathrm{i}$ huset viser Neville Mrs. Herbert et maleri (af tyskeren Januarius Zick) som rummer en dunkel allegori, der tydeligt nok fylder ham med ubehagelige forudanelser: "Do you see, Madam, a narrative in the apparently unrelated episodes? There is drame, is there not, in this overpopulated garden?" Zicks billede er en gådefuld labyrint, en mangetydig handlingskonstellation i mytologiske gevandter, for Neville svanger med mord. Som Compton Ansteys park scenery, et talende billede. 


\section{Den upersonlige kabale}

Men da det drejer sig om en gåde, må publikum spørge sig, hvem der styrer gåden? Tegneren "konstruerer" og forbereder scenen for publikum, fordi vi i så høj grad føres ind i filmen via tegningerne, men en anden reorganiserer den på en måde, som han, tegneren, ikke er på højde med. Alle på Anstey er bundet til andre ved kontrakter, der indgås endog noget så ekstremt og morsomt som seksuelle kontrakter. Alle holder rækken, alle udøver en magt inden for det givne system og til slut er alle magtesløse og instrumentaliserede, tegneren mere end nogen anden. Der råder en enestående høj forbindelse mellem handlingstvang og planløshed.

Det yderst raffinerede ved filmen er det upersonlige net som strammes, den mystiske magt, der styrer begivenhederne som en usynlig hånd, tilsyneladende tilfældigheder begynder at danne et mønster. Begivenheder og forholdsregler justeres ind efter hinanden i et længe flydende spil, for publikum en rebus af fiktive holdepunkter, som til slut danner et mekanisk mønster. Et mønster, der ikke inkarneres af bestemte personer, men som bekræfter en bestemt klasses interesse $\mathrm{i}$ opretholdelse af sine besiddelser, kontraktlige hierarkier, arvefølge m.v.

Ved besættelsen af rollerne sendte Greenaway manuskriptet til en række skuespillere med spørgsmålet, om de kunne se, hvem der står bag mordkomplottet. De der svarede, at det kunne de ikke, blev straks engageret. Anthony Higgins, som spiller Neville, kom under indspilningen af filmen til den konklusion, at hele intrigen på forhånd var tilrettelagt af Mrs. Herbert, datteren og Mr. Noyes og at motivet bestod i, at skaffe $\mathrm{Mr}$. Herbert af vejen, fordi man ikke vidste, hvad der ville blive resultatet af hans tur til Southhampton. Selv hælder jeg til en anden løsning på mordgåden, nemlig at $\mathrm{Mr}$. Herberts hest slet og ret snublede i et muldvarpeskud og kastede sin herre i voldgraven. Hvad der støttes af, at vi forud har fået oplyst, at Mr. Herbert ikke kan svømme, og af at hesten er halt, da den kommer tilbage. I øvrigt omkom kongen, William of Orange, nogle få år senere ved, at hans hest snublede i et muldvarpeskud. Ordet muldvarp bruges i filmen både som betegnelse for undergravende virksomhed og selvfølgelig for det lille dyr, der laver plamager på de ulastelige plæner.

Vi får aldrig noget svar på den kriminalistiske intrige, filmen er et fixérbillede af brandere, gags, ordspil, surrealistiske provokationer, "pictorial conceits" - som Neville siger om Zicks billede - og intellektuelle nøddeknækkeropgaver. Når Descartes, som udtryk for epo- 
kens mekaniske verdensbillede, triumferende kunne sige: "Giv mig udstrækning og bevægelse, og jeg vil konstruere universet", så er filmen denne rationalistiske konstruktion på vrangen, en autonom intrige uden fornuftigt subjekt, et system der følger sine egne love. I slægt med Piranesis "fængselstegninger" fra 1700-tallet, der viser en kæmpemæssig de-centreret verden af platforme, hjul, ramper, trapper og antikke bygningselementer, eller en historie af Borges, hvor centrum opløser sig i et grænseløst net af relationer.

Det urørlige kamera observerer havens "stilleben" i bevægelse og spørgsmålet om virkelighed og reproduceret virkelighed bliver stærkere, som filmen forløber. I et interview henholder Greenaway sig til Oscar Wildes konstatering af, at de sande mysterier altid er overfladiske, hvad filmen bekræfter gennem sin to-dimensionalitet og sin reduktion af begivenhederne til tegning eller tableau. Til sidst brændes tegningerne, hvorved de afgørende vidnesbyrd bringes ud af verden. Filmens elliptiske struktur er ført til ende, og vi sidder tilbage med haven og dens grønne mysterier. Greenaway siger, at han lader tegningerne brænde som et citat fra den berømte slutscene i Orson Welles' "Citizen Kane", hvor publikum er vidne til, at slæden med påskriften Rosebud brænder, en oplysning som kaster et forklarelsens skær tilbage på historien. I Tegnerens kontrakt sidder publikum tilbage som vidner, men uden nøgle, selvom den mekanik som tilintetgør kunstneren til fordel for de besiddendes logik forekommer plausibel og at fungere upåklageligt.

\section{Haven på Anstey}

Greenaway flytter den traditionelle kriminalhistorie fra husets saloner til parken. Ligesom Antonioni i Blow up, hvor hovedpersonen, David Hemmings, gennem stadige forstørrelser af et fotografi af en parkscene kommer på sporet af et mord; en film som i øvrigt har det til fælles med Tegnerens kontrakt, at den er optaget af forholdet mellem billedlig repræsentation og virkelighed.

Tegnerens kontrakt udspiller sig i og omkring et hus i Tudorrenæessance, hvor parken i overensstemmelse med principperne for den engelske have, fremhæver huset inden for et ubrydeligt hele. Haven er et kunstprodukt, men med et tilpas mål af tilrettelagt frihed til at samtidens filosofisk indstillede havearkitekter kunne fremhæve den engelske have som udtryk for Liberty i modsætning til den formmæssigt strengt regulerede - "undertrykkende" - franske have. 
Haven til Compton Anstey er et stykke potenseret natur, svarende til herskabets overvældende parykker. Den er et lystrum for naturen selv, en operascene hvor naturen synger ud og et panorame for de figurer den velvilligt integrerer. En enhed af det reglementerede og det overdådige, som på tærsklen til den romantiske have vil udløse oplevelser og stemninger. I det mindste hvad malerne kaldte "une sensation forte devant la nature" i barok, repræsentativ forstand, hvor naturen spiller diskrete fanfarer. Den stive pomp og pinlighedsskematik hos herrerne på Anstey svarer til havens korsettering, relativ i forhold til den franske barokhaves geometri, men i sine busketter, træer og græsbevoksede åbne linieføringer tilstrækkelig manicureret til at herskabet iført sine rober og kunstfærdige parykker kan posere i samstemmende "naturlig" scenografi. Haven er som filmens intrige åben og dog mekanisk fastlagt. I familie med labyrinten, den barokke manierismes ur-landskab.

Den skønne orden i denne "gentlemens park" betoner samtidig, at den agrare overklasse har naturen til forbundsfælle, naturen i sin lovmæssige, fornuftige orden. Udstillingen af aristokratiets lediggang er vittigt underspillet, tungt arbejde ses overhovedet ikke og selv de gartnere, som ordner Ansteys grønne anlæg, synes at være skabt i billedet af de operette-bønder, som Maria Antoinette mange år senere kunne besøge $\mathrm{i}$ parken til Petit Trianon.

\section{Kedsomhed, død og den arkadiske lykke}

I en af filmens løjerlige replikker hedder det om godsbesidderen Mr. Herbert, at han lader voldgraven gro til, fordi han ikke kan fordrage at se på karperne, "de kan blive meget gamle, ligesom katolikker". En bemærkning, der selvsagt angiver hans dødsangst og peger frem mod hans fatale endeligt blandt fiskene, men som under alle omstændigheder sætter forgængeligheden på dagsordenen.

I skildringen af temaet forgcengelighed bryder Greenaway med sine forbilleder hos malerne. I filmen er der intet af den gyldne dis fra den nedgående sol, det forsonende bløde lys, drømmen om melankolsk mæthed i Lorrains og Poussins heroiske landskaber. Intet af den berømte "guldtone" fra Pæstum, sceneriet er ikke svøbt i patinaens patos, og der forekommer ingen ærværdige ruiner som udtryk for en kostbar, men fingeret og skrøbelig tråd til antikken. Filmen skildrer landskabets elementer i klar belysning med en skarp high tech fotografering præget af direkte udsagn; alle genstande fremstår som håndgribelige størrelser. Hvor filmens billeder eller 
Nevilles tegninger f.eks. genkalder barokteaterets perspektivvirkninger, er det uden de sfæriske, transcendente effekter i dybden. Heller ikke malernes échappée de vue mod det uendelige eller forsøget på at gøre den vide horisonts transcendens til immanens i landskabet, bl.a. ved at kaste et skær af troværdighed over den "problematiske" horisonts vidtløftigheder gennem omhyggelig detaljering af forgrunden, er noget Greenaway inddrager i sin vittige turnering af stoffet. I modsætning til Stanley Kubrick i Barry Lyndon, hvor titelpersonens anti-heroiske gliden hid og did $i$ et skæbneforløb han alt andet end selv kontrollerer, lejlighedsvist bliver udstillet $i$ et vidt . spændende, dårende dejligt totallandskab.

Den illuminerede distance, fornemmelsen af at visionen ikke kan $\mathrm{v}$ are længere end det øjeblik den bliver levende i vores bevidsthed, den søde forgængelighed, meget af dette elimineres i Tegnerens Kontrakt til fordel for koncentrationen i et tæt, afgrænset rum omkring begivenhederne. Afkaldet på den fjerne horisonts metafysiske dybder modsvarer fraværet af det dybere "sjæleliv" hos personerne på Anstey; fraværet af individuel fylde og subjektiv inderlig. hed. Det psykologiske spiller ingen bærende rolle i filmen. Personerne er ornamenter $i$ historien, ikke substans. Som skikkelser i haven dele af den inventariserede natur.

Greenaway viser sig som påvirket af le nouveau roman forstået som "tingsroman". Alt er lagt udenfor og skildres, holdt ud i strakt arm af det affektløse kamera, som figurer $i$ et landskab og som ting $^{2}$. Melankolien, kedsomheden og selv ironien bliver objektiv i dette rum, d.v.s. ophører med primært at være en subjektiv erfaring. Det ydre bliver det indre. Havens eksteriør til interiør.

Aristokraterne på Anstey opfatter haven som et lille Arkadien i en tradition, der i lige linie går tilbage til Medicierne og deres kreds, som allerede på Lorenzo il Magnificos tid løb rundt $i$ haven til villaen ved Fiesolo og legede arkadiske hyrder, i et forsøg på via allegorisk fiktion at knytte forbindelseslinien til antikken. I en lille afhandling viser Panofsky ${ }^{3}$, hvordan forestillingen om Arkadien - et landskab på Peleponnes - undergik en række forandringer i oldtidens litteratur, for hos Virgil at få den form i hvilken Arkadien igen dukker op i renæssancen, som et lyksaligt men tabt landskab. Den elegiske forgængelighed bliver allerede hos Virgil, men siden renæssancen meget ofte bragt til udtryk med et gravmonument indføjet i det arkadiske landskab, der bærer indskriften Et in Arcadia Ego, der enten er blevet læst - oftest fejlagtigt mener Panofsky - som "Også jeg - (den døde) levede i Arkadien" eller som "Selv i Arka- 
dien er jeg (dvs.) døden". Poussin har lavet flere billeder over temaet døden i Arkadien, ét hvor den døde taler til nogle forbipasserende hyrder fra sin sarkofag, et andet og senere, hvor den elegiske følelse af forgængelighed bliver helt dominerende og abstrakt. Tegnerens Kotrakt kan nærliggende ses som en kommentar til den traditionelle sammenkædning af Arkadiens skønne natur og livets endelighed. Omformuleret til en murder story, hvor de arkadiske repræsentationsformer viser sig skæbnesvangre. Enten som ironisk forsvinden, for $\mathrm{Mr}$. Herberts vedkommende i subtil overensstemmelse med repræsentationsformernes balsamering til tom væren, eller som dramatisk, kreaturlig død. I det afsluttende ritualmord på Neville smider de arkadiske hyrder deres fåreklæder og viser sig som ulve.

\section{Frugtsymbolikken}

Det er ikke for ingenting filmen foregår under William of Orange. Filmen dyrker gevækster i alle nuancer af grønt, men vi præsenteres også for frugter $\mathrm{i}$ hobetal fra blommer hvis lighed med damebagdele fremhæves, medens herrerne knuser stenene mellem tænderne, over granatæbler til ananas. Man udveksler erfaringer om, hvordan eksotiske frugter drives frem, giver dem som gaver og retter dem an som nature morte. Den lille dreng Augustus, som Mr. Thalman har taget $\mathrm{i}$ sin forvaring, fordi faderen er død, og moderen er katolik, undervises i alfabetet ud fra frugtnavne: "A für Ananas" osv. Og da Neville vender tilbage til Anstey for at lave den 13. tegning, fortæller Mrs. Herbert ham den klassiske myte om Demeter ("sædmoderen"), gudinde for jordens grugter, hvis datter Kore bliver røvet af underverdenens hersker Pluto og under navnet Persefone gjort til herskerinde over de dødes rige. På grund af Demeters sorg går al vækst i stå og hungersnød truer menneskene. Jupiter må blande sig og tvinger Pluto til at sende Persefone tilbage til dagens lys. Men forinden har Pluto fået Persefone til at suge kernen af et granatæble, og dermed er hun $i$ hans magt. En trediedel af året må hun tilbringe $\mathrm{i}$ underverdenen, to trediedele $\mathrm{i}$ oververdenen. På vore breddegrader vil man umiddelbart fortolke den trediedel, som Persefone tilbringer $\mathrm{i}$ underverdenen som vinteren, jvf. Mr. Nevilles beretning om hertugens drivhus. Men i oldtidens Grækenland refererer perioden til den tid, hvor kornforrået ligger i store lerkar i 
jorden, altså er forvaret hos Pluto. Det vil sige at dødsrigets hersker Pluto er herre over den akkumulerede rigdom, hvorfor han i oldtiden ofte afbildes flankeret af overflødighedshorn.

At myten refereres så udførligt og får så emfatisk en placering i filmen kan næsten kun forklares ud fra mor-datter-forholdet, Mrs. Herbert - Mrs. Thalman. Sarah Thalman kan jo siges at være i Plutos magt, for såvidt som hun i sidste ende lader sig befrugte for at sikre ejendommen, som den impotente Herr Thalmans "stilleben". Vælger gerrigheden fremfor begæret.

\section{Monumenter $i$ bevagelse}

En lignende tvetydeighed, omend med modsat fortegn, kan ses i skildringen af den grotesk vittige joker, som optræder i spillet gentagne gange $i$ form af en levende statue, og som umiddelbart forekommer meget mystisk. I den oprindelige 3 timers version af filmen bliver det forklaret, at det "levende statue" var en almindelig finansiel løsning for godsejere, som ikke havde råd til at anskaffe kopier af antikke statuer og derfor hyrede daglejere til nøgne og indsmurt $i$ farve at illudere statuer i parken. I den korte version af filmen er statuen bizar og uforklaret, en af filmens komplet uhåndterlige, lyriske absurditeter. Snart kravler han rundt på hovedbygningens klassicistiske fronton under en natlig banket i det fri, snart står han som Hercules-statue på en plint. Han kommer og går $i$ haven, umælende og uset af de fleste, en levende statue blandt stive starutter. Mr. Thalmans lille myndling, Augustus, er endnu så ufordærvet, at han kan se ham og undres. Fortabt stirrer han på manden, medens Mr. Thalman slet ikke ænser statuen, blot ihærdigt indprenter Augustus det nyttige $\mathbf{i}$ at lære matematik. For Thalman gælder den ubearbejdede materie som "ond" og tilsvarende den ubearbejdede menneskenatur. Og i parallel modsætning til $\mathrm{Mr}$. Neville, hvis "forhold til naturen er helt materielt", som Mrs. Thalman siger, og som fikserer alt i perspektivrammens gradmønster, laver Augustus tegninger af en anderledes legende frihed. Også statuen, landsbytossen om man vil, yder sit bidrag til kritikken af en bestemt kunsttradition. Oprejst som statue pisser han ned på sin sokkel, samtidig med at han hælder vand ud af en kande, en håndfast leg med Ingres' "Kilden", der hører til de berømte stykker i det 19.århundredes akademiske klassicisme. 
Den levende statue angiver $i$ sin enhed af kunst og liv meget præcist Greenaways egen omgang med (kunst)historien. Ligesom drengen er den et subversivt element og umælende i modsætning til det meget talende selskab på Anstey. Måske er statuen stedets genius, havens ånd, der som hævn fik ejeren Mr. Herberts hest til at snuble i et muldvarpeskud? For derpå at udløse tumult ved at sprede hans beklædningsstykker $i$ haven? I slutscenen, hvor Neville udfører sin tegning af den rytterløse bronzehest, sidder "statuen" faktisk på hesten, hvad Neville ikke ænser. Da han er slået ihjel hopper tossen ned fra hesten, vader igennem voldgraven og bider $\mathrm{i}$ den ananas, Neville fik ved ankomsten. Ananasen, frugtsymbol for gæstevenskab, smager skidt og statuen spytter den ud.

Neville når aldrig at få øjnene op. Så langt fra at ville smigre sine opdragsgiveres forfængelighed, tegner han helt i deres ånd. Som skotsk katolik er han på forhånd på kant med den protestantiske adel, men den autonomi, han som privatperson vil manifestere $\mathrm{i}$ forhold til sine mæcener, udmærker ikke hans kunst. Alligevel er Neville tænkt som en forløber for den autonome kunstner, med Greenaways egne ord: "The artist here is an outsider trying desparetely to get in. He is overdressed and quarrelsome, because that is what the position of the outsider dictates. He is always trying too hard, and getting things wrong". Neville står som kunstner på et udviklingstrin mellem mæcensystemet og det frie marked. Opdragsgiverne ejer hans tegninger og de ydre betingelser for hans arbejde. Fordi han, som det siges i filmen, er en mand "without property and foresight", ejer de i sidste instans også ham selv og kan disponere over ham efter forgodtbefindende, inden for det benhårde kontraktslige univers. Der er i filmen ikke så meget som et øjeblik af oprigtighed, uforfalsket kærlighed eller moralsk retskaffenhed. Kun den tossede statue og barnet har del i noget andet.

\section{Filmens omgang med det historiske}

Tegnerens Kontrakt destruerer de sentimentale forventninger til historiske film. Greenaway nærer en vis afsky for den "realistiske" historiske film, som i hans øjne er en besættelse i engelsk filmproduktion. Og Tegnerens Kontrakt tilfredsstiller da heller ikke historiske perfektionister: parykkerne er større end de var på noget tidspunkt i det 17. århundrede, græsset er grønnere end nogen vil forvente af det engelske landskab mere end tre dage $i$ træk og 
konversationen er mere litterær og tæt end i nogen epoke.

Tilsvarende har komponisten Michael Nyman skabt en musik, som nok bygger på Henry Purcell, der på det nærmeste døde det år filmen finder sted, men som ikke tilstræber at være en pastiche. Nyman har taget melodifragmenter og brudstykker af ostinatbasstemmer fra Purcell og udviklet dem i lukkede, lagdelte og repetitive harmoniske strukturer, der tænkes at modsvare de organisatoriske og tidslige rammer, som udførelsen af tegningerne pålægger livet på Anstey. Og som samtidig skulle gøre hver af de to sæt á 6 tegninger, Neville udfører, "læselige" for publikum, bl.a. igennem at musikstykkerne udvikler sig i takt med tegningerne. Fordi filmen blev så stærkt beklippet er denne intention ikke indløst. Men musikken bevarer den ironiske tilgang til situationer og karakterer, som på alle leder kendetegner filmen.

På trods af den manipulerende omgang med det historiske stof lykkes det at skabe en atmosfære af en epokes anderledeshed, der ligeså overbevisende som i en af de få historiske film, der foregår på samme tid, Mnoukchines Moliere eller for den sags skyld fremragende historiske film som Kubricks Barry Lyndon, Rohmers Die Marquise von $O$. eller Fassbinders Effi Briest. Filmen som alle står i gæld til de billedlige overleveringer fra de pågældende tidsaldre uden dog at underkaste dem en så underfundig ikonografisk leg som Tegnerens Kontrakt.

Elementer af teatralske, sceniske arrangementer findes i sig selv hos de malere, der er Greenaways udgangspunkt. En vis bundløshed i sansningen i det 17. århundredes sujet. I Caravaggios artificielle belysninger eller den potenserede supereksistens i det plastiske og i koloritten hos Vermeer van Delft. Hos samme de hyppigt forekommende delvis fratrukne forhæng i billedets forgrund, der efterligner de dengang almindeligt anvendte klædestykker til beskyttelse af malerier, men som i billedet dublerer rammen, skaber fornemmelsen af teaterscene, en uvirkelig virkelighed etc. Eller de kulisseagtige formationer af træer og silhouetter i forgrunden hos Lorrain.

Det storartede ved Tegnerens Kontrakt består for mig i at filmen forbinder en indsigtsfuld analyse af sit stof med en uhøjtidelig og ikke nostalgisk eksperimenteren, som Greenaway selv siger det: "There is a lot of bogusnes in my scholasticism." Det lykkes ham at få en bestemt historisk periode til at fremstå som en besnærende billeddannelse, samtidig med at filmen er så æestetisk reflekteret, at den bryder sin egen billedrus. Filmen er i sig selv en visuel lærepro- 
ces og tillader publikum at indhente den optiske erfaring. På en legende måde leder den os til forståelsen af, at en anden form for fornuft er forbundet med andre måder at se på, nye se-vaner.

\section{Noter}

1 Jeg tænker her på et bestemt aspekt af det allegoriske hos Walter Benjamin, den melankolske forfatning af det erindrende,allegoriske blik, for hvilket auraens forfald ved tingene samtidig er dens tilblivelse. Det som det allegoriske blik længes efter, nemlig skonhed, varighed, fuldkommenhed, det fornægter allegorikeren, men idet han fornægter det opstår ønsket påny, som længsel efter det uopfyldelige. Han fastholder auraen ved det sønderbrudte - med melankolsk trofasthed. Svarende til samleren der skaber sin egen hemmelige orden i objekterne, som unddrager dem "tingslighedens uvæsen", deres typiske, normgivne klassificering. Interiøret "fremstiller for privatmanden universet. I det samler han det fjerne og fortiden. Hans salon er en loge i verdensteatret." (W. Benjamin Schriften b.I, s.415) Genstandene, som er revet ud af deres naturlige sammenhæng, de er "allegoriske", genopstår i interiører/samlingen som længselsfuldt besatte, fulde af "irrationelle accenter" og hemmelighedsfuld mening.

2 Allerede den film som har betydet mest for Peter Greenaway som film kunstner, Alain Resnais' Ifjor $i$ Marienbad var pávirket af den ny roman, i første række Robbe-Grillet. Måske udgør Michel Butors roman L'emploi $d u$ Temps, der udfolder ideen om at bevismaterialet $\mathrm{i}$ en mordsag er indlejret $\mathrm{i}$ et bestemt kunstværk, et direkte udgangspunkt for Tegnerens Kontrakt.

3 Erwin Panofsky: 'Et in Arcadia Ego: Poussin and the Elegiac Tradition', in: samme, Meaning in the Visual Arts, New York 1955, s. $295 \mathrm{ff}$.

\section{Litteratur om filmen}

Stephen Harvey: Peter Greenaway's Movies: Very English, Very Eccentric, in: The New York Times, 19. juni 1983.

Jean Pierre Jeancolas: La représentation rebelle, in: Positif 276, februar 1984.

Carl-Johan Malmberg: I Motivens labyrint, in: Chaplin 188, november 1983.

\section{Interviews}

Dom Joyeux: Peter Greenaway - en osannolik filmskapare, in: Chaplin 188, november 1983.

Peter Greenaway om "The Draugthsmans Contract", in: præsentationen af konkurrencefilmene ved La Biennale di Venezia, 1982.

Robert Brown: From a View to a Death, dobbeltinterview med filmens producent Peter Sainsbury og instruktøren P. Greenaway, in: Monthly Film Bulletin nr. 586,1982 . 